Archaeological Journal

\title{
Excavations in Hayling Island
}

\author{
Talfourd Ely Esq., M.A., Lit.D., F.S.A.
}

To cite this article: Talfourd Ely Esq., M.A., Lit.D., F.S.A. (1906) Excavations in Hayling Island, Archaeological Journal, 63:1, 117-124, DOI: 10.1080/00665983.1906.10853025

To link to this article: http://dx.doi.org/10.1080/00665983.1906.10853025

$$
\text { 曲 Published online: } 17 \text { Jul } 2014 .
$$

Submit your article to this journal

LII Article views: 2

Q View related articles $\asymp$ 


\section{EXCAVATIONS IN HAYLING ISLAND. ${ }^{1}$}

By TALfodrd ELY, Esq., M.A., Lrt.D., F.S.A.

My Roman Hayling, recently published by Messrs. Taylor and Francis, was written from an historical and literary point of view. The present paper will deal rather with the archaeological results of my excavations, and will include a brief account of the work done both before and since that book appeared.

From its exposed position Hayling Island has suffered much at the hands of the elements. A year or two ago the winds levelled with the ground a hundred stately elms in a single day. The waters, though their attacks are less frequent, have done more permanent damage, about half the island having been washed away in historical times. A third element, fire, has inflicted an appropriate penalty on his unruly brethren by destroying with impartial flames the old windmill at Stoke, and its still more ancient rival, the watermill driven by the tides.

For the misdeeds of her kin, however, their gentler sister, earth, has in part atoned, by sheltering in her fostering bosom the relics of the earliest civilised inhabitants of Hayling.

In 1897 an experimental excavation in the Towncil Field towards the north of the island made it clear that below the surface lay the foundations of a Roman building, and in the following year I traced the outline of walls and flint pavements, finding many nails, with fragments of pottery and wall-plaster.

The most important object discovered, however, was a dupondius of Domitian bearing the date of his seventeenth consulship, that is the year ninety-five of our era. The excellent preservation of this coin shows that it was lost almost immediately after it was minted. We may therefore conclude that the building in which it was found was in existence before the close of the first century. This, however, is not the earliest coin found

1 Read before the Meeting of the Institute, May 2nd, 1906. 
in the Towncil Field. Before I came there an as of Augustus, issued B.c. 29-27, ${ }^{1}$ had been ploughed up ; and I myself have dug up a British stater of the first century before the Christian era, besides a denarius of Augustus, and specimens of the "Second Bross" of Claudius I. and Vespasian.

In 1899 a line of massive foundation, 72 feet in length, was excavated in the adjoining field called "The Long Towncil." Its breadth varied from 3 feet at the northern and southern ends to $10 \frac{1}{2}$ feet near the centre.

In front lay another block of foundation $18 \frac{1}{2}$ feet from north to south, with a width of 4 feet. Around were scattered large quantities of shells, and bones of the ox and the pig.

In the next year I satisfied myself that the above represented the eastern limit of the building, and then turned my attention to the western or larger 'Towncil Field, on the eastern side of which I excavated the walls, and some of the pavement, of a chamber (A on plan) which had been heated by a channelled hypocaust. Of this pavement about a hundred of the limestone tessercae were found, and just outside, at a depth of about a foot, lay a circular brooch of bronze inlaid with blue enamel, of a style belonging to the period of the Roman occupation of this country. I traced a main wall for 103 feet to the north-east angle, and thence westwards for 90 feet.

For convenience we may thus employ the terms north, south, east and west to denote the sides of the square excavated, though in reality the above mentioned main wall runs some 20 degrees east of north, being nearly parallel to the hedge by which the original common field has been divided.

In 1901 my operations were on a more extended scale, involving the removal of hundreds of barrowloads of earth. Three large flint pavements were uncovered, to say nothing of minor excavations, some of which reached to a distance of 170 feet to the west of the hedge.

The objects found included portions of building material, such as roof-tiles and coloured plaster; also

${ }^{1}$ See Numismatic Chronicle, 1904, age, from B.C. 45-3, by II. A. Grueber, Part III, p. 198, Roman Bronze Coin- F.S.A. 
fragments of "Samian" and other pottery ; a few objects of bronze and of iron; and animal remains, such as boars' tusks. Perhaps the most interesting objects were pieces of baked clay, apparently fluted, but really no doubt the remains of "wattle and dab," from which the wood had been burnt out. Hence the charcoal with which they were mixed.

Next year I opened out the foundations of the southern wall, from its south-east angle westward to a distance nearly equal to that reached in 1900 along the parallel foundation on the north. The principal work, however, was the excavation of a parallelogram forming the southeast portion of the site, and measuring 50 feet from north to south, and 30 feet from east to west; the greater portion being within the above mentioned southern wall. Here, and also to the south of the wall, were extensive remains of flint pavement intersected by channels as if for heating purposes, the "finds" including glass and a knife.

During the few days I had to wait before the corn in the Towncil was reaped, I excavated a chamber in a field near Langston Harbour. The pavement was of flint with channels through it. On this pavement were lying fragments of tiles and pieces of wall plaster, some being coloured. The building may have been connected with a pottery which seems to have existed near this spot in Roman times.

In 1903 my excavations began on August 25th and continued, with some short intermissions, to October 27 th. They were certainly more successful than those of the six previous years. I finished tracing the north and the south walls, and uncovered the outer face of the foundations of the western wall, ascertaining that the main buildings formed a square of 132 feet. Near the western end of the north wall there were indications suggesting that there was a gateway at this point. Time, however, did not allow of further excavations, and indeed this portion of the site was latterly completely under water.

Within these main walls, and parallel to them at a distance of from 13 to 16 feet, were inner walls forming no doubt a series of chambers. The width of the foundations of the main walls is 3 feet. 
Tradition asserted the existence of a circle of stone in the interior, and this, by means of diagonal trenches, I found and excavated. Its diameter is between 37 and 38 feet. It probably formed a fishpond, as at 2 feet below the surface I found clay so impervious that at the close of my excavation the water was standing in the circle to the depth of a foot. In one of the above mentioned diagonal trenches there was a considerable amount of opus signinum. Of the coins found the most interesting was a British coin of bronze with the type and general appearance of the British gold staters which were copied from those of Philip II. of Macedon. This is a specimen of ancient forgery. Either it was originally plated with gold, or the maker relied on the brightness of the bronze to pass as gold.

In August, 1904, I once more shouldered my spade, chiefly with the view of investigating the indications of a gateway noted in the previous year.

I soon found that the northern wall, instead of meeting the western, ended abruptly, leaving a distance of $4 \frac{1}{2}$ feet between the two lines of foundation. Almost in the centre of this gap was a rectangular mass of flintwork (B on plan) 2 feet in width, leaving an unoccupied space of 1 foot on the east and $1 \frac{1}{2}$ feet on the west. The latter, like the surrounding ground, was covered with a hard layer or pavement of small flints and gravel, in fact a roadway; while the narrower side space was filled with soft earth, easily removed, and bounded by the sharply defined end of the northern wall. Here apparently was a gateway with folding doors meeting at a post probably fixed in the central stonework. Further excavation pointed to a double gateway, a similar central block being discovered 11 feet 9 inches (or about 12 Roman feet) to the north of the above, while on each side there stretched out a flanking line of foundation intended apparently to protect the entrance, and forming in fact a small court such as is often found in the approaches to ancient buildings. In the neighbourhood of this entrance I excavated extensive foundations lying outside the north wall.

In order to ascertain whether the stone circle discovered in the previous year had been built over older buildings, 
like the similar structure at Caerwent, I laid bare the whole of the exterior, but found no walls actually abutting on it, though there were foundations very near it on the east. The present width of the stone ring varies from 1 foot 11 inches on the south-east to 4 feet 9 inches on the north-east. But measurements made on four sides in 1904 give an average breadth of 3 feet 7 inches.

Further excavations confirmed the opinion that there were several subdivisions formed by interior walls parallel to those bounding the square with others at right angles. There are also indications of channelled hypocausts to the north of the one excavated in 1900 and 1903 .

In the earth dug up in 1904 were found coins of Claudius I. and Vespasian, which support my view as to the very early date of the settlement in question.

Hitherto my excavations had been somewhat sporadic. Last year, therefore, I determined to complete the excavation of a single considerable block - the south-eastern quarter, a space extending some 80 feet from east to west by 67 feet from north to south, portions of which had been examined in previous years. Here I found two more hypocausts ; in them were remains of charcoal, tiles, shells, and coloured plaster, indicative of residential quarters.

The site now excavated occupied the highest part of a "brow" or swelling of the surface, which has long been considered to be artificial. That it is, however, really of natural origin has been proved, I think, by my recent excavations, for flint pavements of large extent are here found within a few inches of the surface, instead of being thickly corered with debris as they would have been if the rise in the level of the ground had been caused by remains of walls, roof, or other human handiwork. There was, indeed, on this side a remarkable dearth of traces of the subdivisions previously mentioned.

My next task was to complete the excavation of the north and south walls, and a portion of the western wall. In the eastern half of the north wall there is a part of the foundation lying at a much lower level than the rest ( $C$ on plan). Either there was here a gate, or the upper portion of the wall foundation has been destrosed for a length of 9 feet. While I was engaged upon this part 
of the excavations a labourer informed me that sixty years ago he and his father were working in the field north of the Towncil when they came upon building material and graves, from which they dug up boxes of bones. On my suggesting that there might have been a road northwards from the Roman settlements in the Towncil Field to "the Wadeway" (the ancient passage to the mainland), he replied that indications of such a road might occisionally be seen in the growing crops. Upon this I made an experimental excavation at a point 143 feet north of the apparent gateway, and about knee-deep found what seemed to be a road formed of flints and gravel, with a few fragments of pottery. The ploughman in the field further north told me he had found one coin, which he had given away as a halfpenny.

Having excavated half the wall of the circle to its full width, I drew diagonal trenches on lines passing through the centre to investigate various points of the site. Near the south-west angle a hypocaust ( $D$ on plan) of considerable size was discovered. In this neighbourhood, close to the western termination of the south wall, there is an abrupt fall of 4 inches in the level of the wall foundation ( $\mathrm{E}$ on plan), similar to that already mentioned as occurring in the north wall. This depression is 7 feet in length. A slight set back near the south end of the west wall, and a very small chamber or cell opposite suggest a gateway at this spot, and this would correspond with the gateway in the north wall excavated in 1904. This year, however, I found no indication of a central block, and no outer gateway, so the lower level may be accidental.

Trenches dug across the north-eastern quarter revealed some stonework, and yielded so much in the way of shells and of broken pottery, both black and "Samian," as to suggest that systematic excavation here would prore fruitful of interesting results. Time, however, was not sufficient for further work.

Now as to the nature and purpose of the structure. The square enclosure appears to have contained more than one house, and several outbuildings. The flint walls and pavements outside were, no doubt, intended for cattle. The settlement was founded at a very early date, and 
continued to exist probably to the close of the Roman occupation of Britain, the latest coins found being a follis of Constantine, struck in London about A.D. 315, a centenionalis of the same emperor, minted between A.D. 335 and 337, and a follis of Constantius II., of about A.D. 354.

Among the objects found which merit attention are a somewhat peculiar stilus and a fragment of a bronze bracelet, also of unusual pattern.

I have to thank Mr. H. A. Grueber and his colleagues at the British Museum for valuable help in compiling the appended list of coins found on the site. It will be seen that although the first is the only one in the list that can be claimed as unique, the extent of time represented by these coins-some four centuries-is worthy of remark.

\section{Date. Reverse.}

1. British Stater $\ldots \quad \ldots$ First century Rude horse.

2. Denarius of Augustus $\quad \ldots \quad$ A.D. 1-14 $\quad \ldots \quad$ Figures of Caius and

3. Dupondius (Double As, or "Second Brass") of Claudius I.

4. do. do.

5. Dupondius (Double $A$ s, or "Second Brass") of Vespasian.

6. Dupondius (Double $A s$, or "Second Brass") of Domitian.

7 do. do.

8. Dupondius (Double $A s$, or "Second Brass") of Hadrian.

9. Dupondius (Double $A s$, or "Second Brass") of Antoninus Pius.

10. Follis of Constantine I. ... circ. $315 \quad \ldots$ Sol to left (struck

11. Centenionalis of Constan- 335-337 ... Victory holding tine I.

12 Follis of Constantius II. ... circ. $354 \quad \ldots \quad$ The Emperor and spear and shield. (On the Obverse, bust of Constantinopolis.)

Victory in a boat. Felicitas temporum reparatio. 
I have had the opportunity of examining the following four coins found in the Towncil Field before my operations began, and now in the possession of Mr. F. Trigg :-

DATE.

a. As of Augustus $\quad \ldots \quad \ldots \quad \ldots \quad$ B.c. 29-27.

b. Denarius of Antoninus Pius ... $\quad \ldots$ A.D.

c. Dupondius of Faustina ... ... " 141-161.

$d$. British imitation of coin of Postumus " 258-267.

Other interesting objects found by me were :Bronze and enamel brooch.

$\begin{aligned} \text { Bronze } & \begin{array}{l}\text { Bastgle. } \\ \text { P Portion of bracelet. } \\ \text { i set of toilet implements. }\end{array} \\ \text { Iron }\left\{\begin{array}{l}\text { Key. } \\ \text { Knife. } \\ \text { Stilus. }\end{array}\right. & \end{aligned}$ 


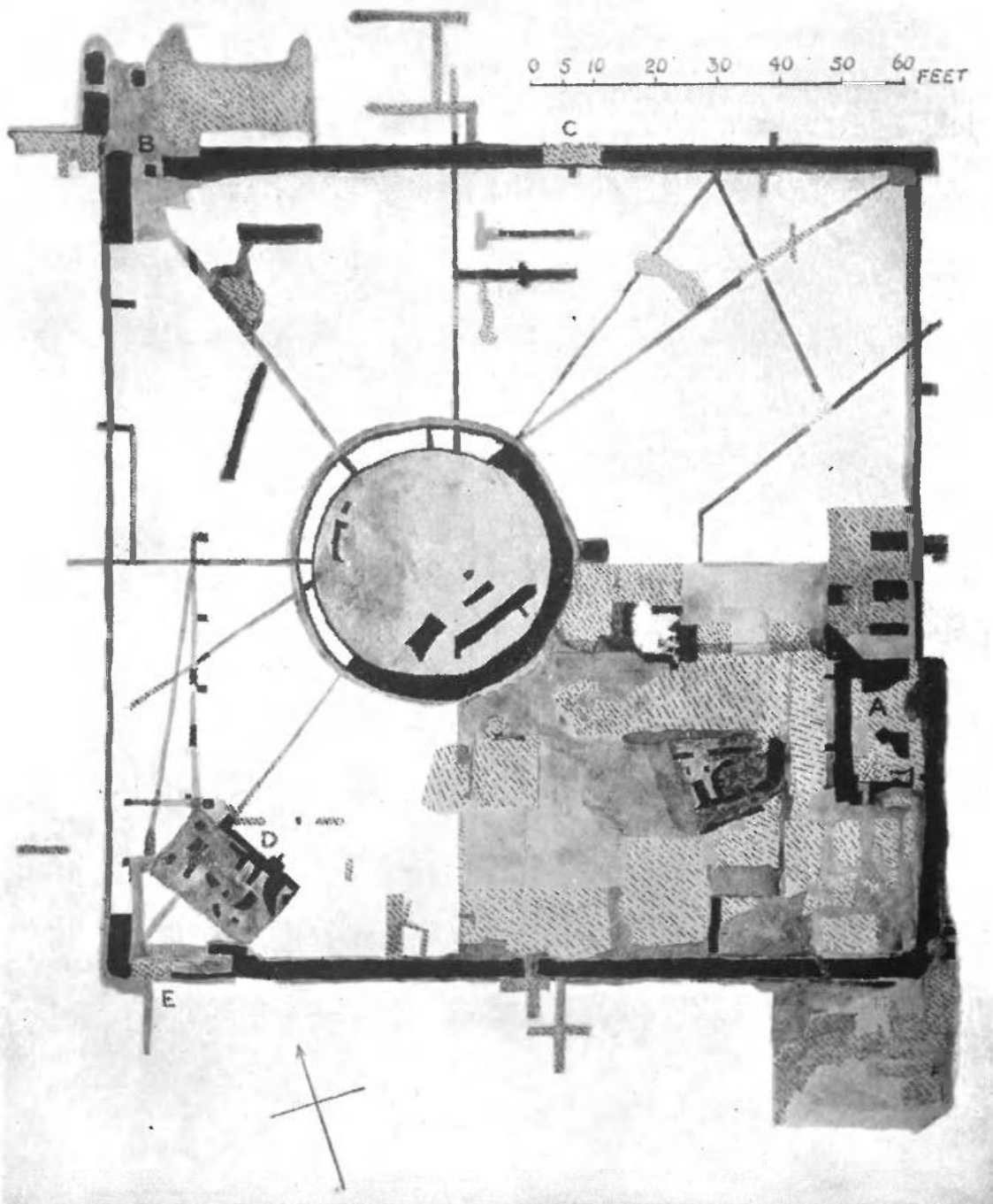

PLAN OF EXCAYATIONS IN HAYLING ISLAXD. 